\title{
DIREITO DE PREEMPÇÃO: AS DIVERSAS ESPÉCIES DE PREFERÊNCIA NO DIREITO CIVIL
}

\author{
RIGHT OF PREEMPTION: THE SEVERAL KINDS OF PREFERENCE IN CIVIL LAW
}

Danilo Haddad Jafet ${ }^{*}$

\begin{abstract}
Resumo:
O presente artigo abordará as espécies mais relevantes de direito de preempção ou preferência no Direito Civil brasileiro, passando, inicialmente, pela preempção convencional, momento em que serão traçados os principais aspectos do instituto da preempção. Em seguida, serão estudadas as preempções do condômino, do coerdeiro, do locatário, do arrendatário e, por fim, o instituto da retrocessão.
\end{abstract}

Palavras-chave: Preempção. Preferência. Retrocessão.

\begin{abstract}
:
This paper discusses the most relevant kinds of preemption rights in the Brazilian Civil Law. The first topic is about the conventional right of preemption and at this moment, the main aspects of the institute of preemption will be outlined. Subsequently, the following figures shall be studied: preemptions of the joint ownership, of the co-heir, of the lessee, of the rural lessee and, finally, retrocession.
\end{abstract}

Keywords: Preemption. Right of preference. Retrocession.

Introdução

Não raras vezes, o Direito elege determinados sujeitos para figurar em situação de vantagem sobre os demais sujeitos, quando diante da mesma situação. Normalmente, isto ocorre como forma de proteção da pessoa ou, até mesmo, para dar prestígio a um instituto ou a uma relação jurídica. Esta posição privilegiada é popularmente conhecida como "preferência", ou, em termos mais técnicos, "preempção".

O vocábulo "preempção" é composto pelo advérbio latino prae (antes) e pelo substantivo latino emptio (compra) e quer dizer, na literalidade, "compra contratada por antecipação" ou "preferência para compra". Na terminologia jurídica, preempção exprime a preferência na aquisição de certa coisa, conforme anteriormente pactuado ou por disposição legal. Já o vocábulo "preferência" vem do latim praeferens, de praeferre (pôr em primeiro lugar, preferir) e quer significar, originalmente, a vantagem que coloca determinada pessoa ou coisa em primeiro lugar ou antes de outra, com o intuito de beneficiá-la (SILVA, 1978, p. 1.200 e 1.202). Ensina Álvaro Villaça Azevedo (2011, p.

\footnotetext{
* Danilo Haddad Jafet é advogado, graduado pela Faculdade de Direito da Universidade de São Paulo, mestre em Direito Civil e especialista em Processo Civil pela mesma instituição (jafet_d@yahoo.com.br).
} 
351) que a palavra "preferência" é formada pelo mesmo advérbio prae e pelo verbo latino emere (comprar), significando, etimologicamente, preferência na compra. Preempção e preferência são sinônimos, com o mesmo significado jurídico. ${ }^{1}$

Neste artigo, foram selecionadas as modalidades de preferência mais relevantes para o Direito Civil. Serão estudadas, então, a preferência convencional e as preferências legais do condômino, do coerdeiro, do locatário e do arrendatário. Por fim, será feita breve reflexão sobre o instituto da retrocessão, muitas vezes chamado de preferência ou prelação legal.

\section{Preempção ou preferência convencional:}

\subsection{Definição e contornos}

A preempção é a cláusula especial, ou pacto adjeto, ao contrato de compra e venda, pela qual estipulam as partes que, caso o comprador queira vender ou dar em pagamento a coisa objeto da contratação, fica ele obrigado a dar preferência ao vendedor, tanto por tanto. A preempção envolve duas condições sucessivas: primeiro, é preciso que, após a compra e venda originária, o comprador queira vender a coisa que comprou e, segundo, que o vendedor a queira de volta, exercendo seu direito de preferência na compra. Trata-se de obrigação unilateral, porque, caso intencione vender a coisa, deve o comprador comunicar o vendedor, mas este não tem nenhuma obrigação de adquiri-la. Pelo contrário, tem apenas a faculdade de exercer o direito ou não. A compra e venda feita aperfeiçoa-se de forma completa e definitiva, mesmo com a cláusula de preempção, pela qual, em resumo, "o comprador promete que, quando quiser eventualmente vender a coisa ou dá-la em pagamento, dará preferência ao antigo vendedor de comprá-la" (AZEVEDO, 2011, p. 352).

No Brasil, o direito de preempção é personalíssimo, instituído exclusivamente no interesse do titular. Não pode esse direito ser cedido e nem transmitido mortis causa, como preceitua o art. 520 do Código Civil. Em outras ordens jurídicas, a cessão e a transmissão aos herdeiros podem ser pactuadas pelas partes. ${ }^{2}$ A obrigação do comprador de dar a preferência ao vendedor, por outro lado, esta sim é transmitida aos seus herdeiros.

\footnotetext{
A legislação brasileira faz uso, ainda, de um terceiro sinônimo, a "prelação", que vem do latim praelatio.

2 Vide-se, por exemplo, o disposto no art. 420 do Código Civil português: "o direito e a obrigação de preferência não são transmissíveis em vida nem por morte, salvo estipulação em contrário". Na Argentina, por outro lado, a preferência também é direito personalíssimo, a teor do disposto no art. 1.165 do Código Civil argentino: Pacto de preferencia es aquel por el cual el vendedor tiene derecho a recuperar la cosa con prelación a cualquier otro adquirente si el comprador decide enaje-narla. El derecho que otorga es personal y no puede cederse ni pasa a los herederos.
} 
A cláusula de preempção não exige forma especial e, como regra, segue a sorte do contrato de compra e venda. Nada impede, contudo, que a compra e venda de um imóvel de baixo valor ou de um bem móvel se formalize por meio de instrumento público, por faculdade das partes, e o pacto de preferência se formalize por instrumento particular posterior. $^{3}$

O direito de preferência só alcança alienações nas formas de venda ou dação em pagamento, como expresso pelo art. 513 do Código Civil. E nem poderia ser diferente, porque outras formas de alienação são incompatíveis com o exercício deste direito. Na permuta, por exemplo, o alienante tenciona trocar seu bem por outro bem certo e determinado. Não faria sentido que o vendedor invocasse a preferência caso o comprador estivesse negociando a troca do bem por bem de terceiro, porque aqui não satisfaria o comprador receber dinheiro pela coisa, mas tão somente outra coisa específica. Se o comprador quisesse, em outra situação, doar o bem a terceiro, tampouco poderia o vendedor se valer da preferência para recuperar a coisa entregando dinheiro como contrapartida. Mais uma vez, o interesse do comprador não estaria sendo preservado.

Outro limite imposto, também de forma lógica, diz respeito à sujeição exclusiva do direito real de propriedade à preempção. ${ }^{4} \mathrm{~A}$ preferência não poderá ser suscitada quando se estiver diante de qualquer outro direito real. Nesse sentido, o comprador poderá constituir usufruto, servidão ou direito de habitação sobre o bem, bem como dá-lo em garantia por meio de penhor - se móvel - ou hipoteca e anticrese - se imóvel -, sem que isto signifique violação ao direito de preferência do vendedor.

\subsection{Retrovenda x preempção x opção de compra}

A falta de afinidade com os institutos da preempção, da retrovenda e da opção de compra poderia levar a uma confusão das figuras, porque, como se verá, o resultado alcançado com o exercício dos três direitos pode ser o mesmo, ou seja, a reaquisição do bem pelo vendedor originário.

Na retrovenda, o vendedor de coisa imóvel pode reservar-se o direito de recobrá-la no prazo decadencial máximo de três anos, restituindo o preço recebido e reembolsando eventuais despesas havidas pelo comprador. Isso significa que a venda é feita em caráter resolúvel, ou seja, pode vir a se resolver, à exclusiva vontade do vendedor,

\footnotetext{
3 Leciona Nelson Nery Júnior que "o direito de preferência pode ser objeto de convenção inteiramente autônoma" (NERY JÚNIOR, 2009, p. 596).

4 O art. 1.152 do Código Civil de 1916 dispunha que: "o direito de preempção não se estende se não as situações indicadas nos arts. 1.149 e 1.150 , nem a outro direito real que não a propriedade". O referido dispositivo não encontra correspondente no atual Código Civil, o que não significa que a limitação permanece, porque, como mencionado, ela é decorrência natural do próprio direito de preferência.
} 
ocasião em que ele readquirirá a coisa, com efeito retroativo, como se sempre tivesse sido sua. Aqui, não há imposto de transmissão pela volta do bem ao patrimônio do vendedor, tampouco persistem eventuais ônus reais instituídos enquanto a coisa tiver estado com o comprador. A vontade do comprador pouco importa, bastando que o vendedor deseje recuperar a coisa para que a retrovenda se aperfeiçoe.

Já a compra e venda feita com pacto adjeto de preferência se aperfeiçoa de forma integral e definitiva, ainda que o direito de preempção venha a ser invocado no futuro. Se isto ocorrer, estar-se-á diante de novo negócio jurídico, completamente autônomo quanto ao primeiro, mas que recairá sobre o mesmo bem e terá como partes as mesmas da compra e venda originária, agora ocupando posições inversas. A diferença maior é que, diversamente da retrovenda, na venda com cláusula de preferência, o comprador não se obriga a devolver a coisa ao vendedor à exclusiva vontade deste, mas apenas promete que, caso pretenda vendê-la, dará preferência a este último. Nesse caso, haverá incidência de imposto de transmissão e os direitos reais constituídos sobre o bem enquanto ele tiver sido propriedade do comprador deverão permanecer.

Por fim, a opção consiste em promessa unilateral feita por alguém, de vender determinado bem a determinada pessoa, por preço estipulado de comum acordo, caso esta deseje adquiri-lo dentro de prazo também ajustado previamente. Como ensina Orlando Gomes (1959, p. 274), “a opção pode encerrar o direito de preferência para comprar a coisa, mas sob a forma de privilégio, que não é concedido necessariamente ao vendedor e não supõe venda anterior".

\subsection{Exercício do direito}

No momento em que as partes estipulam a cláusula de preferência, podem elas optar entre duas sistemáticas distintas, contidas no art. 515 do Código Civil - "aquele que exerce a preferência está, sob pena de a perder, obrigado a pagar, em condições iguais, o preço encontrado, ou o ajustado". Pode ser, então, que tenha ficado contratado que o vendedor, no exercício da preferência: $(i)$ pagará o preço que o comprador tiver encontrado em negociação com terceiro interessado; ou ( $i i)$ pagará o preço que tiver sido previamente fixado entre ele, vendedor, e o comprador, no momento em que a venda originária foi contratada.

Para que o vendedor possa exercer seu direito de prelação, deve o comprador comunicá-lo de sua intenção de venda, concedendo o prazo previamente estipulado entre as partes, para que o vendedor se manifeste positiva ou negativamente. ${ }^{5}$ Caso as

Ensina Agostinho Alvim (1961, p. 202) que o prazo "não é apenas para responder, e sim para exercer o seu direito, isto é, para efetuar o negócio". 
partes não tenham fixado prazo na cláusula de preempção, os prazos serão de três dias para coisa móvel e sessenta dias para coisa imóvel, de acordo com o art. 516 do Código Civil. O termo inicial destes prazos é o dia seguinte ao recebimento da comunicação pelo vendedor. Tratam-se de prazos decadenciais, que não se interrompem, não se suspendem e tampouco se dilatam. Se o direito não for exercido dentro destes prazos, caduca, ou seja, se extingue de plano, nada mais podendo o vendedor exigir do comprador. O silêncio do vendedor é equiparado a uma manifestação de vontade em sentido negativo (TUCCI; AZEVEDO, 1995, p. 47).

A lei não estabelece forma especial para a notificação a ser feita. Desse modo, pode o comprador interpelar o vendedor judicial ou extrajudicialmente, por meio de Cartório de Títulos e Documentos ou não, bastando tão somente que fique comprovada a ciência do vendedor quanto aos termos da notificação.

O momento da notificação deve ser aquele em que o comprador já tiver uma oferta concreta de terceiro interessado na aquisição do bem. Nesse sentido, a interpelação deverá conter todos os elementos necessários para que o vendedor possa exercer a prelação tanto por tanto, ou seja, adquirir a coisa nas mesmas condições, pelo menos, propostas pelo terceiro interessado, se tiver ficado pactuado que a preferência seria exercida sobre o preço encontrado. O comprador precisa informar ao vendedor o preço, as condições de pagamento e outros detalhes da negociação, tais como eventuais garantias oferecidas pelo terceiro, além dos juros e do índice de correção monetária convencionados.

Já no caso de terem as partes previamente estipulado preço certo a ser pago pelo vendedor no caso de exercício da preempção, é irrelevante o preço pretendido por terceiro interessado, pois seja o novo preço maior ou menor que o pré-ajustado, deverá este prevalecer sobre aquele se o vendedor decidir adquirir o bem no prazo a ele concedido (ALVIM, 1961, p. 204-205).

Recebida a notificação, poderá o vendedor agir de três formas. Se ficar inerte e deixar transcorrer o prazo decadencial, verá caducar seu direito de preempção. Por outro lado, se não tiver nenhum interesse na aquisição do bem nas condições propostas, poderá simplesmente se manifestar negativamente, liberando o comprador para efetivar a negociação com o terceiro interessado. Por fim, poderá aceitar os exatos termos da proposta, de modo inequívoco. Se a aceitação se der em desconformidade com a proposta, não haverá formação do contrato, mas apenas uma contraproposta feita pelo vendedor. ${ }^{6} \mathrm{Se}$ a aceitação se der de forma dúbia, criando dúvidas quanto ao seu conteúdo, ou se for sob condição ou termo, caducará o direito de preferência.

\footnotetext{
6 Álvaro Villaça de Azevedo (2011, p. 362) defende que a aceitação diversa da proposta feita por terceiro só valerá se trouxer maiores vantagens ao primitivo comprador.
} 
Caso o vendedor suspeite que o comprador esteja negociando o bem com terceiro sem a intenção de lhe conceder prazo para exercício da preferência, poderá ele se antecipar e interpelar o comprador do seu direito, a teor do que dispõe o art. 514 do Código Civil. Como se verá adiante, esta intimação não tem o condão de impedir a alienação a terceiro, mas vale apenas como advertência ao comprador, mostrando a vigilância do vendedor.

Prevê o art. 517 do Código Civil que, quando o direito de preempção tiver sido estipulado em favor de dois ou mais sujeitos em comum, deverá ser exercido sobre a coisa no seu todo. Isso significa que os vendedores titulares da preferência deverão exercê-la como condôminos e a coisa será considerada indivisível, independentemente de sua natureza, simplesmente por força legal. E mais, devem os pretendentes exercer seus respectivos direitos dentro do mesmo prazo comum, nunca em prazos sucessivos.

Se algum dos vendedores não exercer a prelação ou perder o direito de invocá-la, este direito passa aos demais, ou seja, continuarão eles exercendo a preferência sobre o todo, aumentando-se, proporcionalmente à quota do desistente, suas frações ideais da coisa. Se a preferência não fosse exercida sobre o todo, com a desistência de um dos pretendentes, o comprador poderia acabar se vendo obrigado a vender sua coisa em parte, o que provavelmente diminuiria sensivelmente seu valor e dificultaria a venda (LACERDA, 1981, p. 41).

\subsection{Natureza jurídica da preempção convencional}

A consequência legal pela violação ao direito de preferência, por meio da venda do bem a terceiro sem a devida comunicação prévia ao vendedor originário, é a responsabilidade do comprador originário por perdas e danos eventualmente sofridos pelo vendedor. Não se discute a validade e a eficácia da venda feita a terceiro, a qual o vendedor jamais conseguirá impedir ou desfazer. A preferência convencional no ordenamento jurídico brasileiro é direito pessoal, que cria liame jurídico entre o seu titular e o sujeito passivo da obrigação de fazer e que, por outro lado, não confere ao seu titular poder jurídico erga omnes a possibilitar a sequela no caso de alienação em desrespeito ao direito do vendedor. Nas palavras de Orlando Gomes (1959, p. 291):

Se o direito do vendedor tem natureza real, como nos sistemas jurídicos que assim o regulam, cabe-lhe depositar o preço para obter a coisa. Mas se não tem esse caráter, como em nosso Direito, assiste-lhe apenas o direito pessoal contra o comprador de haver perdas e danos. Assegurase-lhe o direito de exercer a prelação, em curtos prazos de decadência conforme seja o bem móvel ou imóvel, mas tão somente para o fim de ressarcimento dos prejuízos sofridos pelo titular. Com efeito, responde por perdas e danos o 
comprador, se ao vendedor não der ciência do preço e das vantagens que the oferecerem pela coisa. A venda sem cumprimento da obrigação de afrontar é válida. O titular do direito de prelação não pode anulá-la.

Não restam dúvidas, pela leitura literal do texto do art. 518 do Código Civil, que, de fato, se trata de direito pessoal. Ainda assim, uma parte bastante minoritária da doutrina brasileira defende a eficácia real do direito de preempção. Argumenta Arnaldo Rizzardo (2006, p. 334-335) que a ação apropriada para o exercício do direito seria a reivindicatória, cumulada com a anulatória do ato, a se dirigir em face do terceiro adquirente, enquanto que o comprador primitivo responderia por perdas e danos. Assim, o art. 513 do Código Civil autorizaria o exercício do direito de preferência, com caráter real, e o art. 518 autorizaria, ainda, o ressarcimento dos prejuízos acarretados ao vendedor pelo descumprimento das regras pelo comprador. Se assim não fosse, entende o autor, "a par de constituir o instituto uma figura em desuso, nenhuma força prática terá se ensejar a mera indenização por perdas e danos. Desaparecerá a finalidade que o inspirou, permitindo a transgressão das normas que o regulamentam sem o mentor Constrangimento".

Com a devida vênia, parece que o posicionamento sustentado pelo jurista deve ser encarado somente como crítica ao atual sistema legal, porque vai diametralmente contra o texto expresso da norma. Se fosse a intenção do legislador ter dado eficácia de direito real ao direito de preferência convencional, certamente isto teria ficado claro, seja no texto do art. 513, seja no texto do art. 518, como, por exemplo, ocorre com o art. 504 do Código Civil que, ao tratar da preferência do condômino, prevê a possibilidade de adjudicação do bem.

Realmente, a natureza do direito de preferência é uma escolha legislativa. Em Portugal, por exemplo, a regra é que a preempção tenha efeitos meramente obrigacionais. Contudo, se previamente pactuado entre as partes, poderá ter eficácia de direito real. ${ }^{7}$ Já o direito alemão permite duas classes de direito de preferência, uma meramente pessoal (arts. 504 e seguintes do Código Civil alemão) e outra com efeitos reais (arts. 1.094 e seguintes do mesmo diploma) (AZEVEDO, 2011, p. 367).

$\mathrm{O}$ art. 518 do Código Civil inovou em relação ao seu correspondente no Código Civil de 1916, ao prever que, além do comprador, também responderá o adquirente, de forma solidária, pelas perdas e danos, desde que tenha agido com má-fé. Assim, responderá o comprador pela sua clara omissão na ausência de comunicação, ou por deixar de constar na notificação algum dos elementos necessários para que o vendedor exerça

Nos termos do art. 421 do Código Civil Português: "o direito de preferência pode, por convenção das partes, gozar de eficácia real se, respeitando a bens imóveis, ou a móveis sujeitos a registo, forem observados os requisitos de forma e de publicidade exigidos no artigo 413 ". 
com segurança seu direito de preempção, ou pela prestação de informações inverídicas, como, por exemplo, informar ao vendedor preço superior ao efetivamente negociado com o terceiro adquirente. Se quanto a qualquer um destes atos o terceiro adquirente tenha tido ciência ou efetiva participação, poderá ele ser igualmente responsabilizado pelos prejuízos sofridos.

Como se trata de responsabilidade solidária, poderá o vendedor lesado acionar o comprador e o terceiro adquirente ou somente um deles, à sua escolha, o que não significará renúncia ao direito de, posteriormente, acionar o outro. Mas precisa ficar claro que o terceiro deve ter agido com culpa para que possa ser responsabilizado, ou seja, ainda que por omissão, deve ele ter pretendido a frustração do direito de preferência do vendedor. Para se resguardar, recomenda-se que, em se tratando de bem imóvel, o terceiro analise tanto a certidão de registro imobiliário quanto o inteiro teor da escritura de aquisição, para verificar a existência ou não de pacto de preempção (AZEVEDO, 2011, p. 369).

O vendedor lesado terá prazos decadenciais de 180 dias, se a coisa for móvel, ou dois anos, se imóvel, para propor ação de perdas e danos contra o primitivo comprador e, eventualmente, contra o terceiro adquirente. Nesta ação, precisará o vendedor comprovar, sucessivamente, duas situações: $(i)$ que tinha efetivas condições de adquirir o bem no momento em que seu direito de preferência restou frustrado; e (ii) que realmente sofreu prejuízos ou deixou de aferir lucros em função da preterição. ${ }^{8}$

Uma vez notificado o primitivo vendedor, a desistência do primitivo comprador em realmente efetuar a venda também pode ensejar perdas e danos. Do mesmo modo, caso o vendedor, uma vez tendo se manifestado positivamente quanto ao exercício da preferência, desista de efetivamente adquirir o bem, poderá ser responsabilizado por eventuais perdas e danos sofridos pelo comprador, que podem compreender, por exemplo, a perda do negócio com o terceiro que realizou a proposta objeto da preferência.

\footnotetext{
8 Mostra-se valiosa a análise de um caso concreto para que fique ilustrada a necessidade de comprovação de perdas e danos: "Dizendo de outro modo, o pacto de preempção gera direito estritamente pessoal entre comprador e vendedor, imponível ao terceiro adquirente. A ação de violação do pacto de preempção é somente indenizatória, e não reipersecutória. (...) O autor não pode pleitear o valor equivalente ao preço da venda que violou a preempção (R\$ 9.000,00), pois não suportou esse prejuízo, nem desembolsou qualquer outro valor. $O$ dano possível, em decorrência da violação ao direito de preferência, corresponderia à diferença entre o valor de venda do imóvel e o valor de mercado, se este fosse maior do que aquele. De fato, se o autor houvesse recomprado o imóvel pelo valor da venda, em princípio seu patrimônio não teria acréscimo quantitativo, mas simples alteração de natureza, pois em parte passaria a consistir em bem imóvel em vez de dinheiro. Haveria lucro apenas se a aquisição ocorresse por preço menor que o valor real do bem, dado pelo mercado". (Apelação Cível n. 0004498-54.2013.8.26.0077/TJSP, Relator o Desembargador Francisco Loureiro, julgado em 11/08/2015).
} 


\section{Preferências legais}

Traçados todos os principais contornos do instituto da preempção ou preferência convencional, cuidará este artigo, a partir de agora, das espécies mais relevantes de preferência legal, ou seja, aquela instituída pela lei em favor de um dos sujeitos da relação jurídica, independentemente da vontade das partes, a quem o legislador, para prestigiar ou proteger, confere a prelação de adquirir o bem em condições idênticas às ofertadas por outros interessados. Muitas das características da preempção convencional estão também presentes nas modalidades de preferência legal, razão pela qual só se trará, nas linhas abaixo, as novidades e diferenças de cada uma destas espécies.

\subsection{Preferência do condômino}

O condomínio pode ser definido como a propriedade exercida por mais de um sujeito, ao mesmo tempo, sobre a mesma coisa indivisível. O direito de cada proprietário existe em conjunto sobre a coisa comum, nunca sobre uma porção certa e determinada dela. Os condôminos são proprietários concorrentes e simultâneos e cada um é, então, detentor de uma fração ideal da coisa.

O condomínio só existe em função da indivisibilidade da coisa, que impossibilita o exercício do direito de cada proprietário sobre uma parte material determinada do bem. A indivisão pode ser: $(i)$ física ou natural, que importa impossibilidade fática de divisão da coisa sem a desestruturar ou sem prejudicar seu uso, como, por exemplo, um animal ou uma casa; (ii) econômica, se a divisão física for possível, mas condenável, porque fará com que o objeto perca consideravelmente seu valor (tem-se, aqui, o clássico exemplo do corte de um diamante em dois menores); (iii) legal, como a impossibilidade de divisão da ação ou da quota social, menor expressão patrimonial da empresa; ou ( $i v$ ) consensual, como ocorre quando as partes determinam a indivisibilidade de determinado lote de mercadorias, para atender às exigências do mercado, garantindo sua venda por preço maior.

Por envolver uma pluralidade de sujeitos titulares de direitos sobre o mesmo bem, o condomínio traz uma grande potencialidade de conflitos entre estas pessoas e é, portanto enxergado pelo Direito como um estado de tensão criador de fonte de discórdia. Não por outro motivo, entre os romanos, o condomínio era conhecido como mater rixarum (mãe das rixas). Com o intuito de cessar ou diminuir as chances de desentendimentos entre os condôminos, o Direito facilita a extinção do condomínio sempre que possível.

Desse modo, o condômino de coisa indivisível não pode vender sua fração ideal a estranhos se outro condômino a quiser, tanto por tanto. Por meio do disposto no art. 504 do Código Civil, pretende a lei conciliar os objetivos particulares do condômino 
alienante com os objetivos coletivos da comunidade de coproprietários. Geralmente, é mais cômodo e desejável manter a propriedade entre os titulares originários do que permitir a entrada de um estranho no grupo, que poderia intensificar tensões já existentes ou trazer novas chances de conflitos.

O exercício do direito de preferência do condômino pode trazer o fim desejado pela lei, se forem apenas dois os condôminos e um resolver vender sua parte para o outro, venda esta que significará a extinção do condomínio. Se forem mais de dois condôminos, o condomínio não se extinguirá, mas, ao menos, restarão menos condôminos, o que provavelmente diminuirá as chances de desentendimentos futuros.

O tex to da lei é claro: o direito de preferência só existirá se um dos condôminos pretender alienar o bem a terceiros, estranhos ao condomínio. Se um coproprietário desejar vender a coisa a outro condômino, não há que se falar em preferência, o que faz todo o sentido, pois, neste caso, não há risco de participar da relação jurídica um novo sujeito. ${ }^{9}$

A lei estabelece uma ordem de preferência entre os próprios condôminos interessados em exercer o direito de preempção. Assim, sendo dois ou mais os interessados, preferirá o que tiver benfeitorias de maior valor na coisa. Se nenhum deles tiver benfeitorias, poderá exercer a preempção o que tiver maior quinhão. Se não atendidos quaisquer dos dois critérios de desempate, valerá a regra geral já mencionada, ou seja, adquirirão o quinhão como condôminos, depositando o respectivo preço e aumentando proporcionalmente seus quinhões.

Deverá, então, o condômino alienante comunicar os demais condôminos para que, querendo, exerçam seu direito de preferência, obedecendo aos mesmos requisitos da comunicação feita no caso de preempção convencional. Diante do silêncio da lei, é pertinente o questionamento feito por Álvaro Villaça Azevedo (2011, p. 29) quanto ao prazo em que deverão os condôminos se manifestar positiva ou negativamente, respondido pelo próprio jurista: “entendo que, na interpelação, deverá constar um prazo para resposta, que seja razoável, nunca inferior a trinta dias; se não constar esse prazo, será o concedido pelo art. 504 in fine, à adjudicação após depósito do preço, ou seja, de cento e oitenta dias". A sugestão de que o prazo mínimo seja de trinta dias decorre da aplicação analógica da lei de locações, que prevê este prazo legal - trinta dias - para o exercício do direito de preferência do locatário, que serviria como mínimo no caso do condômino, podendo ser dilatado por vontade das partes.

Embora não devesse emergir qualquer dúvida a este respeito, posto que a disposição legal é inequívoca, na VIII Jornada de Direito Civil, realizada pelo Conselho da Justiça Federal em abril de 2018, foi aprovado o seguinte enunciado: "ENUNCIADO 623 - Art. 504: Ainda que sejam muitos os condôminos, não há direito de preferência na venda da fração de um bem entre dois coproprietários, pois a regra prevista no art. 504, parágrafo único, do Código Civil, visa somente a resolver eventual concorrência entre condôminos na alienação da fração a estranhos ao condomínio". 


\title{
2.1.1. Natureza jurídica da preferência do condômino
}

Em caso de violação, pelo condômino alienante, do direito de preferência dos demais condôminos, deixando de lhes dar conhecimento da venda feita a terceiro, poderá qualquer um deles depositar o preço em juízo, no prazo decadencial de 180 dias, e haver para si a parte vendida. O prazo decadencial começa a correr a partir do conhecimento efetivo da venda, pelo condômino, que presumidamente se dá com o registro imobiliário.

Aqui sim se está diante do que a maior parte da doutrina reconhece ser um direito real, porque o condômino lesado pode perseguir a fração ideal do bem e adjudicála para si, desde que deposite o preço certo da venda, dentro do prazo decadencial (NORONHA, 2013). Uma parte da doutrina - com a qual se identifica o autor deste artigo -, contudo, entende se tratar de direito pessoal, mas dotado de eficácia real, porque presente a sequela. ${ }^{10}$ Agostinho Alvim (1961, p. 196), ao refutar que o direito de preempção convencional se trataria de direito real, expressa que:

\begin{abstract}
Aliás, quando mesmo o julgássemos provido dêste [sic] atributo, não o consideraríamos, só por isso, um direito real, cujo número é limitado, pois o legislador, segundo sempre temos entendido, adotou a enumeração taxativa (Código Civil, art. 674: numerus clausus), sem embargo de existirem certos direitos intermediários, ou intercalares, entre os pessoais e os reais.
\end{abstract}

O art. 504 do Código Civil não prevê a possibilidade de resolução em perdas e danos do inadimplemento da obrigação de comunicar os condôminos para exercício da preferência. Para Belizário Antônio de Lacerda, o silêncio da lei foi intencional. O legislador teria objetivado, com isto, o cumprimento in specie em detrimento da conversão da coisa perdida em seu equivalente pecuniário, justamente para evitar o aumento da potencialidade de discórdias que traria a entrada de um estranho no condomínio (LACERDA, 1981, p. 27).

\subsubsection{Indivisibilidade $\mathrm{x}$ estado de indivisão}

Como já evidenciado, o art. 504 do Código Civil concede direito de preferência ao condômino quando houver venda de quinhão de coisa indivisível. Questão extremamente polêmica tanto na doutrina quanto na jurisprudência é saber se existe ou não direito de preferência do condômino quando se está diante de bem que, apesar de se

\footnotetext{
10 "A natureza jurídica da preempção ou preferência é a de um direito pessoal, embora possa ter como acessório um direito real" (LACERDA, 1981, p. 2).
} 
encontrar em estado de indivisão, seja passível de ser dividido. São duas as correntes, cada uma em sentido oposto à outra.

Para parte da doutrina, a venda do bem divisível, mas em estado de indivisão, como é o caso de terreno ainda não dividido no momento da venda de uma quota parte por um dos condôminos, prescindiria da abertura de prazo para exercício de preferência pelos outros condôminos. Isso porque, sendo o bem passível de divisão, o condômino que estiver insatisfeito com a entrada de estranho no condomínio tem a possibilidade de promover a divisão da coisa, pondo fim aos inconvenientes de um condomínio demasiadamente problemático. A norma prevista no art. 504 do Código Civil é restritiva da autonomia privada, porque limita, em certo sentido, o direito de livre negociação e alienação do bem pelo condômino alienante e, justamente por isso, não admitiria interpretação extensiva para exigir a preferência também no caso de bens divisíveis. ${ }^{11}$

A segunda corrente doutrinária entende pela necessidade de conferir direito de preferência aos demais condôminos, seja quanto à alienação de bem indivisível, seja quanto à alienação de bem divisível, mas em estado de indivisão. Para estes autores, a inconveniência da entrada de um estranho no condomínio é a mesma em ambos os casos. A solução apresentada pela primeira corrente não seria satisfatória, porque muitas vezes os bens naturalmente divisíveis, quando divididos efetivamente sofrem significativa perda de valor.

Ademais, a interpretação do disposto no art. 504 do Código Civil deve ser sistemática, ou seja, deve levar em consideração o disposto no parágrafo único do art. 1.314, que diz que "nenhum dos condôminos pode alterar a destinação da coisa comum, nem dar posse, uso ou gozo dela a estranhos, sem o consenso dos outros”. Aqui, não há nenhuma menção à indivisibilidade do bem. Não seria coerente exigir anuência dos demais condôminos para dar posse da coisa comum a terceiros e, por outro lado, relativizar esta exigência quando da alienação desta mesma coisa a estranhos ao condomínio, que é situação mais gravosa. ${ }^{12}$

A jurisprudência do Superior Tribunal de Justiça é bastante oscilante quanto ao tema. A Quarta Turma julgou a matéria algumas vezes, tendo decidido, ao menos em quatro ocasiões - nos Recursos Especiais ns. 9.934/SP, 71.731/SP, 88.408/SP e 1.207.129/ $\mathrm{MG}$-, pelo cabimento do direito de preferência em caso de condomínio de bem divisível em estado de indivisão. Por outro lado, o posicionamento histórico da Terceira Turma é contrário, o que se pode conferir no teor dos Recursos Especiais ns. 7.525/SP, 20.446/

11 Neste sentido, confira-se: Carvalho Santos (1953, p. 168-169); Gonçalves (2004, p. 220) e Tartuce (2015, p. 668-669).

12 Para mais: Bevilaqua (1958, p. 249-250); Mendonça (1957, p. 328); Azevedo Júnior (2005, p. 79-80) e Rodrigues Júnior (2008, p. 292-293). 
CE e 60.656/SP. Em 2004, a Segunda Seção seguiu o entendimento da Quarta Turma, no Recurso Especial n. 489.860/SP. De todos os julgados, vale colacionar trechos do já citado Recurso Especial n. 1.207.129/MG:

1. O condômino que desejar alhear a fração ideal de bem em estado de indivisão, seja ele divisivel ou indivisivel, deverá dar preferência ao comunheiro da sua aquisição. Interpretação do art. 504 do CC/2002 em consonância com o precedente da Segunda Seção do STJ (REsp n. 489.860/ SP, Rel. Ministra Nancy Andrighi), exarado ainda sob a égide do CC/1916.

3. Ademais, ao conceder o direito de preferência aos demais condôminos, pretendeu o legislador conciliar os objetivos particulares do vendedor com o intuito da comunidade de coproprietários. Certamente, a função social recomenda ser mais cômodo manter a propriedade entre os titulares originários, evitando desentendimento com a entrada de um estranho no grupo.

4. Deve-se levar em conta, ainda, o sistema jurídico como um todo, notadamente o parágrafo único do art. 1.314 do CC/2002, que veda ao condômino, sem prévia aquiescência dos outros, dar posse, uso ou gozo da propriedade a estranhos (que são um minus em relação à transferência de propriedade), somado ao art. 504 do mesmo diploma, que proíbe que o condômino em coisa indivisível venda a sua parte a estranhos, se outro consorte a quiser, tanto por tanto.

5. Não se pode olvidar que, muitas vezes, na prática, mostra-se extremamente difícil a prova da indivisibilidade. Precedente: REsp 9.934/SP, Rel. Ministro Sálvio de Figueiredo Teixeira, Quarta Turma" (Recurso Especial n. 1.207.129-MG, Relator o Ministro Luis Felipe Salomão, julgado em 16/06/2015).

Parece mesmo que a interpretação mais sistemática do art. 504 do Código Civil foi expressada pelo Ministro Luis Felipe Salomão conforme acima, porque só assim estarão efetivamente alinhados os interesses do condômino alienante, de um lado, e dos condôminos resistentes, de outro, em consonância com a regra exarada pelo parágrafo único do art. 1.314 do Código Civil, a evitar problemas de ordem fática decorrentes da dificuldade de se comprovar a divisibilidade ou a indivisibilidade do bem. 


\subsection{A preferência do coerdeiro}

A herança é transmitida aos herdeiros legítimos e testamentários, automaticamente, no exato momento em que o seu autor morre. Com isto, evita-se qualquer lapso temporal em que os bens ficariam sem titularidade. A partir de então, os herdeiros passam a ter o domínio e a posse sobre todos os bens transmitidos em conjunto, como uma universalidade indivisível. Desse momento até a partilha dos bens, no término do inventário, qualquer dos herdeiros tem direito de reclamar a universalidade da herança em face de terceiros. Aqui, cada herdeiro é titular de um quinhão ideal da totalidade dos bens deixados. São os herdeiros, em outras palavras, condôminos da herança.

Como já visto, havendo condomínio, o condômino que desejar alienar sua fração ideal deve dar oportunidade aos demais condôminos para que exerçam direito de preferência na compra, tanto por tanto. O mesmo deve acontecer quando o alienante for coerdeiro, nos termos do art. 1.794 do Código Civil, sob pena de o coerdeiro frustrado no seu direito de preferência adjudicar a quota hereditária vendida para si, desde que deposite o preço em juízo no prazo decadencial de 180 dias após a transmissão, conforme prevê o art. 1.795 do Código Civil.

A única diferença entre o direito de preferência do coerdeiro e a do condômino vem disposta no parágrafo único do art. 1.795 do Código Civil, que não prevê os critérios de desempate contidos no parágrafo único do art. 504. Assim, em caso de pluralidade de interessados, o quinhão cedido será distribuído entre eles, na proporção das respectivas quotas hereditárias.

\subsection{A preferência do locatário}

O contrato de locação tem acentuada índole social. A locação comercial possibilita o funcionamento do comerciante, que desempenha verdadeira função social, porque gera empregos, arrecadação de tributos, produção e circulação de mercadorias. A locação residencial garante a concretização do direito fundamental à moradia. Seja qual for a modalidade de locação, há interesse social em manter o locatário no imóvel que já vem ocupando ao longo do tempo.

Sensíveis à importância para a sociedade da estabilidade das relações locatícias e, mais que isso, da preservação do locatário no imóvel, as leis locatícias vêm, sucessivamente, desde a Lei n. 3.912, de 3 de julho de 1961, garantindo o direito de preferência ao locatário na aquisição do imóvel por ele locado. Na atual lei de locações, a Lei n. 8.245, de 18 de outubro de 1991 ("Lei de Locações"), o direito de preferência é regulado pelos arts. 27 a 34 . 
Sempre que pretender realizar alienação onerosa, consistente na venda, na promessa de venda, na cessão ou na promessa de cessão de direitos, ou na dação em pagamento, o locador $^{13}$ de prédio urbano residencial, comercial ou industrial, deverá comunicar o locatário, por qualquer meio de ciência inequívoca, para que, no prazo de trinta dias do recebimento da comunicação, exerça seu direito de preferência, sob pena de caducidade.

Por outro lado, o direito de preferência do locatário não alcançará as hipóteses de: (i) perda da propriedade, em que não há sequer alienação, mas extinção do direito de propriedade e, portanto, não há que se falar em preempção; (ii) venda por decisão judicial, que extrapola a manifestação de vontade isolada do locador, sendo considerada como transferência forçada de propriedade, incompatível, portanto com a figura da preferência; (iii) permuta e doação, que, conforme já exposto, tampouco são compatíveis com o instituto da preempção; (iv) integralização de capital, cisão, fusão e incorporação, que são atos societários de interesse específico dos sócios de determinada pessoa jurídica. Seria absurdo imaginar o exercício do direito de preferência, pelo qual o inquilino acabaria por adentrar na sociedade, em contrariedade à vontade dos demais sócios; e $(v)$ constituição de propriedade fiduciária e perda de propriedade ou venda por quaisquer formas de realização de garantias, inclusive mediante leilão judicial, desde que estas condições constem do contrato de locação, em cláusula que se destaque das demais por sua apresentação gráfica. Aqui, não se está diante de alienação onerosa propriamente dita, mas mais perto daquelas hipóteses de constituição de outros direitos reais sobre o bem, com os quais não é compatível o direito de preferência.

Não raras vezes, encontra-se cláusulas de renúncia antecipada ao direito de preferência do locatário no próprio contrato de locação. Nestes casos, a renúncia abstrata nasce junto com o direito, sem que o locatário possa, ao menos, ter ciência das condições da futura alienação, que pode acabar se mostrando interessante a ele no caso concreto. Os Tribunais de Justiça têm decidido, com acerto, pela invalidade de cláusulas de renúncia antecipada, a teor do disposto no art. 45 da Lei de Locações: "São nulas de pleno direito as cláusulas do contrato de locação que visem a elidir os objetivos da presente lei". ${ }^{14}$

Se o imóvel objeto da locação for também objeto de condomínio e, desejando um dos condôminos vendê-lo, deve o direito de preferência do condômino prevalecer

13 Tucci e Azevedo (1995, p. 44) lembram que, na verdade, nem sempre quem aliena o imóvel é o locador, que pode ser, por exemplo, apenas usufrutuário do prédio alugado. Além disso, pode o alienante ser pessoa diversa do proprietário, como é o caso do compromissário vendedor que ainda não figura, efetivamente, como proprietário.

14 Neste sentido, confira-se o recente acórdão proferido pelo Tribunal de Justiça de São Paulo, nos autos da Apelação Cível n. 0114809-04.2008.8.26.0008, Relator o Desembargador Theodureto Camargo, julgada em $16 / 06 / 2015$. 
sobre o do locatário. É o que dispõe o art. 34 da Lei de Locações. Esta prevalência justifica-se porque, de um lado, evita a entrada de terceiro estranho no condomínio - neste caso, o locatário - e, de outro, contribui para a diminuição do número de condôminos e, eventualmente, até para a extinção do condomínio.

Caso o imóvel locado seja objeto de sublocação, também terá o sublocatário direito de preferência na sua aquisição, desde que a sublocação alcance todo o imóvel. E mais, o direito do sublocatário prevalecerá sobre o do locatário, nos termos do art. 30 da Lei de Locações. Se houver pluralidade de sublocatários interessados, deverão eles adquirir o imóvel como um todo, em comunhão, na qualidade de condôminos.

Não havendo sublocatários ou se nenhum demonstrar interesse na aquisição do imóvel, pode o locatário exercer seu direito de preferência. Na eventualidade de haver mais de um locatário interessado, a Lei de Locações estabelece critério de desempate entre eles: a preferência será do locatário mais antigo e, se da mesma data, do locatário mais idoso. Curioso notar que a lei optou por conceder tratamentos diferentes nas hipóteses de pluralidade de sublocatários e de locatários.

Se o mesmo locador for proprietário de diversas unidades autônomas do mesmo prédio e pretender vendê-las como um todo, o direito de preferência deverá incidir sobre a totalidade dos bens objeto da alienação. Deve o locatário, então, exercer sua preferência de forma global. O exercício de preferência quanto a uma ou outra unidade autônoma poderia colocar em risco a inteireza do negócio. Embora os objetos da prestação sejam naturalmente divisíveis, a obrigação é considerada indivisível, no melhor interesse do alienante.

\subsubsection{Natureza jurídica da preferência do locatário}

Preceitua o art. 33 da Lei de Locações que o locatário preterido no seu direito de preferência poderá escolher uma dentre duas opções: $(i)$ reclamar do alienante perdas e danos eventualmente sofridos; ou (ii) proceder à adjudicação judicial do imóvel, desde que deposite o preço certo de venda e as demais despesas tidas com o ato de transferência da propriedade, dentro do prazo de 6 meses contados do registro da alienação na matrícula imobiliária, desde que o contrato de locação tenha sido averbado na referida matrícula com trinta dias de antecedência da alienação.

Aqui, está-se diante de dois direitos diferentes. O primeiro deles trata-se de direito puramente obrigacional ou pessoal, de recuperar os prejuízos havidos e os ganhos que poderiam ter surgido. O segundo trata-se de direito real de tomar o bem para si, por meio de ação real reipersecutória, como defende a maioria da doutrina, ou de direito pessoal com eficácia real, com se optou por classificá-lo neste artigo. 
A doutrina majoritária entende que, se o contrato de locação não tiver sido averbado na matrícula do imóvel com antecedência mínima de trinta dias da alienação, o locatário não terá direito com eficácia real de tomar o bem para si, mas tão somente poderá ajuizar ação reparatória para reaver eventuais perdas e danos sofridos..$^{15}$ É realmente o que está escrito no caput do art. 33 da Lei de Locações. Ainda assim, parte da doutrina sustenta que, caso o contrato de locação não tenha sido averbado na matrícula do imóvel com antecedência mínima de trinta dias da alienação, não terá o locatário qualquer direito de preferência, tampouco poderá exigir perdas e danos ou adjudicar o imóvel alienado junto a terceiro (TUCCI; AZEVEDO, 1995, p. 54). ${ }^{16}$

O art. 29 da Lei de Locações dispõe que, uma vez aceita a proposta pelo locatário, a posterior desistência de efetuar a venda, pelo locador, dá ensejo à responsabilidade por perdas e danos. Aqui, é importante apenas ressaltar que somente as perdas e danos serão efetivamente devidos, se comprovados, não podendo o locatário adjudicar o bem para si, justamente porque, neste caso, não terá havido alienação em desrespeito ao direito de preferência, mas pura e simples desistência do negócio. Por outro lado, caso a desistência seja praticada pelo locatário, também deve este ficar sujeito ao ressarcimento de perdas e danos eventualmente sofridos pelo locador, notadamente com a frustração do negócio que pode ter deixado de celebrar com terceiro.

\subsection{A preferência do arrendatário}

O contrato de arrendamento rural é um instrumento típico de direito agrário, regido por normas de caráter público e social, cuja finalidade é a proteção daqueles que tornam a terra produtiva pelo seu trabalho, dando efetividade à função social da propriedade. $\mathrm{O}$ contrato de arrendamento tem caráter protecionista da pessoa do campo e o direito de preferência previsto no art. 92 , parágrafos $3^{\circ}$ e $4^{\circ}$ da Lei n. 4.504 , de 30 de novembro de 1964 ("Estatuto da Terra") e nos arts. 45 a 47 do Decreto n. 59.566, de 14 de novembro de 1966, é um dos instrumentos legais para atingir esse fim, garantindo que a exploração da terra continue se dando pelo arrendatário que lá já esteja situado.

Dispõem os referidos artigos que o proprietário do imóvel rural deverá notificar o arrendatário para, no prazo decadencial de trinta dias contados da notificação, exercer o seu direito de preferência.

15 Diniz (2014, p. 170); Venosa (2005, p. 156-157) e Souza (2012, p. 153).

16 Quanto a este tema, o Superior Tribunal de Justiça já se manifestou diversas vezes: "Nos termos da jurisprudência desta Corte, a inobservância do direito de preferência do locatário na aquisição do imóvel enseja o pedido de perdas e danos, que não se condiciona ao prévio registro do contrato de locação na matrícula imobiliária. Precedentes" (Agravo Regimental no Recurso Especial n. 1.356.049-RS, Relator o Ministro Ricardo Villas Bôas Cueva, julgado em 25/02/2014). 
Assim como todos os direitos de preferência já estudados, também o direito de preempção do arrendatário deve ser exercido para aquisição total da área, porque não se pode obrigar que o proprietário venda somente parcelas do imóvel, diminuindo-lhe o valor, apenas para satisfazer as preferências individuais de cada arrendatário. A área do imóvel vendido deve ser considerada indivisível, ou seja, a preferência deve recair sobre a sua totalidade, ainda que o arrendamento recaia apenas sobre parte dele. Assim, em caso de pluralidade de arrendatários, desistindo um deles do exercício de seu direito de preferência, os outros poderão adquirir o imóvel em conjunto, inclusive a parte ideal que caberia ao desistente, de forma proporcional.

Em caso de violação do direito de preferência do arrendatário, poderá ele se socorrer de uma das seguintes possibilidades: ( $i$ ) depositar em juízo o preço da venda, mais as despesas com a transferência, no prazo decadencial de seis meses a contar do registro da escritura de alienação na matrícula imobiliária, e proceder à adjudicação compulsória do imóvel; ou ( $i i)$ ajuizar ação de indenização por perdas e danos eventualmente sofridos.

A legislação é silente quanto à eventual colisão de direitos de preferência do arrendatário e do condômino do imóvel. Parece muito razoável a aplicação analógica do disposto no art. 34 da Lei de Locações, no sentido de que a preferência do condômino deveria prevalecer sobre a preferência do arrendatário, pelos mesmos motivos que prevalece sobre a preferência do locatário.

\section{Retrocessão}

O último tópico do presente artigo será dedicado ao breve estudo da chamada retrocessão, regulada pelo Código Civil em seu art. 519, na mesma subseção que trata da preempção convencional, embora sejam institutos completamente diversos. Dispõe o referido dispositivo legal que: "se a coisa expropriada para fins de necessidade ou utilidade pública, ou por interesse social, não tiver o destino para que se desapropriou, ou não for utilizada em obras ou serviços públicos, caberá ao expropriado direito de preferência, pelo preço atual da coisa".

A retrocessão se configura como dever do ente expropriante de oferecer ao expropriado a coisa desapropriada, pelo seu preço atual de mercado, caso não lhe dê a destinação primariamente pretendida, nem sequer se destine a coisa para atender a fins de necessidade ou utilidade pública ou de interesse social, ou, ainda, para utilização em obras e serviços públicos. Ensina Álvaro Villaça Azevedo (2011, p. 371), escudado nas lições de Caio Mário da Silva Pereira, que "não se cuida de um novo contrato, mas de reaquisição do bem expropriado, pela cessação dos efeitos da desapropriação, implicando a retrocessão uma fictio iuris de não ter a coisa saído do domínio do expropriado". 
Como se vê do próprio conceito da retrocessão, não se trata de direito de preferência na aquisição de bem, mas tão somente de faculdade do expropriado de receber a coisa de volta, devolvendo ao ente expropriante o preço recebido, atualizado pelo valor atual de mercado.

São três as principais teorias que versam sobre a natureza jurídica da retrocessão. Pela primeira, entende-se que a retrocessão seria um direito real em face do direito constitucional de propriedade. Pela segunda, entende-se que a retrocessão seria mero direito pessoal que não ensejaria a reivindicação do bem pelo particular, ou seja, ao expropriado restaria apenas perseguir eventuais perdas e danos. Pela terceira, conhecida como teoria mista, entende-se que o ente expropriado poderá reivindicar o bem para si e, caso isto seja inviável, haverá resolução em perdas e danos. Atualmente, a teoria mista tem sido muito aceita por todos os tribunais pátrios, incluindo o Superior Tribunal de Justiça. ${ }^{17}$

\section{Conclusão}

Ao longo deste artigo, foram analisados os principais traços do direito de preempção convencional, bem como dos direitos de preempção legal mais relevantes dentro do campo do Direito Civil, quais sejam, os do condômino, do coerdeiro, do locatário e do arrendatário.

Interessante é o fato de que, como visto, a natureza do direito de preempção é escolha pura e simples do legislador. No Brasil, a preempção consensual é direito meramente pessoal, enquanto em Portugal, em regra, trata-se de direito pessoal, mas que poderá receber eficácia de direito real, a depender da vontade das partes no momento da contratação.

Mais adiante, foi possível verificar que, diante de interesses e direitos colidentes, o legislador brasileiro escolheu qual deve prevalecer. Assim, o direito de preferência do condômino prevalece sobre o do locatário e o do sublocatário. Se se estiver diante apenas destes dois últimos, prevalecerá o direito do sublocatário.

Finalmente, verificou-se que o instituto da retrocessão, considerado por muitos como hipótese de preempção ou prelação legal, na verdade, é figura totalmente diversa das outras previamente analisadas.

São Paulo, 20 de abril de 2019.

17 Confira-se: EDcl nos EDcl no Recurso Especial n. 841.399/SP; Recursos Especiais ns. 943.604/CE e 868.655/MG. 


\section{Referências}

ALVIM, Agostinho. Da compra e venda e da troca. 1. ed. São Paulo: Forense, 1961.

AZEVEDO JÚNIOR, José Osório de. Compra e venda, troca ou permuta. São Paulo: Revista dos Tribunais, 2005.

AZEVEDO, Álvaro Villaça. Comentários ao novo código civil: das várias espécies de contrato, da compra e venda, do compromisso de compra e venda arts. 481 a 532. 2. ed. Rio de Janeiro: Forense, 2011. v. 7. Coleção organizada por Sálvio de Figueiredo Teixeira.

BEVILAQUA, Clóvis. Código civil dos Estados Unidos do Brasil. 5. ed. Rio de Janeiro: Francisco Alves, 1958. v. 4.

CASSAROTTE, Marijane Fernanda. O direito de preferência e suas peculiaridades. Revista Síntese Direito Imobiliário, São Paulo, v. 4, n. 21, p. 22-52, maio/jun. 2014.

DINIZ, Maria Helena. Lei de locações de imóveis urbanos comentada: (Lei n. 8.245, de 18-101991). 13. ed. São Paulo: Saraiva, 2014.

DINIZ, Maria Helena. Tratado teórico e prático dos contratos. 6. ed. São Paulo: Saraiva, 2006. v. 1 e 2 .

GOMES, Orlando. Contratos. 1. ed. Rio de Janeiro: Forense, 1959.

GONÇALVES, Carlos Roberto. Direito civil brasileiro. São Paulo: Saraiva, 2004. v. 3: Contratos e atos unilaterais.

LACERDA, Belizário Antônio de. Do direito e da ação de preferência: doutrina, jurisprudência, prática, legislação. São Paulo: Saraiva, 1981.

LÓPEZ ALARCÓN, Mariano. El derecho de preferencia. Anales de la Universidad de Murcia, Murcia, v. 18, n. 1, p. 5-251, 1960. Disponível em: https://digitum.um.es/digitum/ handle/10201/12227.

MALUF, Carlos Alberto Dabus. O condomínio tradicional no direito civil. 2. ed. São Paulo: Saraiva, 1989.

MARCELINO, Américo Joaquim. Da preferência: estudos, notas da doutrina e jurisprudência e legislação mais comum. 2. ed. Coimbra: Coimbra Ed., 2002.

MENDONÇA, Manuel Inácio Carvalho de. Contratos no direito civil brasileiro. 4. ed. Forense, 1957. v. 1.

NERY JÚNIOR, Nelson. Código civil comentado. 7. ed. São Paulo: Revista dos Tribunais, 2009.

NORONHA, Fernando. Direito das obrigações. 4. ed. São Paulo: Saraiva, 2013.

PEREIRA, Caio Mário da Silva. Instituições de direito civil. 14. ed. São Paulo: Forense, 2004. 
RIZZARDO, Arnaldo. Contratos. 6. ed. Rio de Janeiro: Forense, 2006.

RODRIGUES JÚNIOR, Otavio Luiz; AZEVEDO, Álvaro Villaça (coord.). Código civil comentado: artigos 481 a 537. São Paulo: Atlas, 2008. v. 6, t. 1.

SANTOS, João Manoel de Carvalho. Código civil brasileiro, interpretado. 8. ed. Rio de Janeiro: Freitas Bastos, 1953. v. 16.

SILVA, Oscar José de Plácido e. Vocabulário jurídico. 5. ed. Rio de Janeiro: Forense, 1978. v. 20.

SOUZA, Sylvio Capanema de. A lei do inquilinato comentada artigo por artigo. 8. ed. Rio de Janeiro: Forense, 2012.

TARTUCE, Flávio. Manual de direito civil. 5. ed., rev., atual. e ampl. São Paulo: Método, 2015.

TUCCI, Rogério Lauria; AZEVEDO, Álvaro Villaça. Direito de preferência. Revista do Advogado, São Paulo, n. 45, p. 41-56, jan. 1995.

VENOSA, Sílvio de Salvo. Lei do inquilinato comentada: doutrina e prática. 8. ed. São Paulo: Atlas, 2005. 
